\title{
Effects of coral bleaching on tissue regeneration potential and colony survival
}

\author{
Erik H. Meesters ${ }^{1,3}$, Rolf P. M. Bak ${ }^{2,3}$ \\ ${ }^{1}$ Carmabi Institute, PO Box 2090, Curaçao, Netherlands Antilles \\ ${ }^{2}$ Netherlands Institute for Sea Research (NIOZ), PO Box 59, 1790 AB Den Burg, Texel, The Netherlands \\ ${ }^{3}$ Institute of Taxonomic Zoology, PO Box 4766, 1009 AT Amsterdam, The Netherlands
}

\begin{abstract}
We assessed the influence of coral 'bleaching' on the regenerative potential of corals in a series of field experiments with artificial lesions on colony surfaces. These lesions were made during a mass bleaching event in 1990 on normally coloured and bleached colonies of 3 species: Montastrea annularis, the main reef-building coral in the Caribbean, Porites astreoides, a relatively common and opportunistic coral, and Meandrina meandrites, a species common on the deeper reef slope Regeneration characteristics studied included rate of tissue growth, recovery of lesion area and restoration of tissue colour. Tissue regeneration rates were lower in all species when comparing bleached with unbleached colonies, although there were species-specific differences. Long-term exposure to increased temperature probably affects regeneration, as bleached colonies of $P$. astreoides in the thermal effluent of a power plant regenerated as rapidly as normal colonies situated upcurrent and downcurrent of the power plant. Colour recovery of bleached colonies was closely associated with seawater temperature. When ambient seawater temperature started to decrease $\left(<30^{\circ} \mathrm{C}\right)$, colonies began to regain their normal colour. Colour restoration was slowest in $M$. annularis. Normal colour of coral colonies in the power plant effluent returned at the same time, but at temperatures $2^{\circ} \mathrm{C}$ higher than elsewhere on the reef. Mortality on bleached colonies of $M$. annularis and $P$. astreoides was higher than on normal colonies $131 \mathrm{~d}$ after the start of the regeneration experiments. Large parts of the colony died when the tissue was already regaining its normal colour and lesion regeneration was almost completed. Mortality was most severe for colonies in the effluent. We recorded the sensitivity of coral species to bleaching in surveys over the reef downcurrent and upcurrent of the power plant. These showed that community structure and colony condition on the shallow terrace downcurrent differed noticeably from the upcurrent site. Downcurrent, species diversity was lower mainly because of high densities of Porites astreoides and Diploria strigosa. Bleaching was also more prominent downcurrent. The decreased regeneration rates and increased mortality of bleached colonies (in Montastrea annularis in $30 \%$ of the colonies), during and subsequent to bleaching, clearly indicate the increased vulnerability of coral reefs during periods of thermal stress. Coral reef management should consider limiting activities resulting in small lesions under periods of increased environmental stress.
\end{abstract}

\section{INTRODUCTION}

Corals are prone to damage by a multitude of agents, such as hurricanes (Stoddart 1963), sedimentation (Bak \& Elgershuizen 1976, Bak 1978), temperature changes (Roberts et al. 1982), emersion at low tide (Loya 1972), predation (Ott \& Lewis 1972, Endean 1973, Bak \& van Eys 1975), competition (Lang \& Chornesky 1990), and man (Brown \& Howard 1985). Because of their clonal characteristics (Jackson \& Coates 1986), mortality of coral colonies will often be only partial and result in a patch of bare skeleton, a lesion that is (wholly or partly) surrounded by the remaining living tissue. Such a lesion can become a permanent feature, colonised by competing organisms (e.g. algae and excavating sponges), but often a colony will restore its former integrity through the regeneration of tissue and skeleton (Loya 1976, Bak et al. 1977, Bak \& Stewardvan Es 1980, Bak 1983).

Regeneration plays a fundamental role in colony survival. Because it requires energy, regeneration affects growth (Bak 1983), reproduction (Rinkevich \& Loya 1989), and probably also resistance to diseases and competitive ability. 
A phenomenon of widespread global occurrence on coral reefs that attracts much attention of reef scientists is 'bleaching' (e.g. Brown 1990). Bleaching of corals is associated with the loss of zooxanthella pigment, either by decreasing the cellular concentration of chlorophyll per zooxanthella or by the expulsion of zooxanthellae (Kinzie et al. 1984, Szmant \& Gassman 1990). As a result the coral tissue loses its colour, and colonies turn white because the white skeleton reflects through the tissue. Ecological and physiological research on bleaching of reef corals repeatedly stressed the crucial role of elevated temperatures in bleaching (Jokiel \& Coles 1974, Glynn 1984, Lasker et al. 1984, Cook et al. 1990, Gates 1990, Jokiel \& Coles 1990). Elevated temperatures affect coral growth, calcification, photosynthesis, respiration and reproduction (Clausen \& Roth 1975, Coles \& Jokiel 1977, 1978, Jokiel \& Coles 1977, Jokiel \& Guinther 1978). Field studies have reported the cessation of growth (Goreau \& Macfarlane 1990) and reproduction (Szmant \& Gassman 1990) in bleached corals. Bleaching appears to be potentially relevant to an energy-demanding, vital process such as regeneration.

To study the effects of bleaching on the regeneration capabilities and survival of coral colonies, we carried out in situ experiments with 3 hermatypic zooxanthellate coral species in a period preceded by increasing seawater temperatures and a mass bleaching event. To study the effect of long-term elevated temperatures on regeneration, we have compared regeneration characteristics of bleached corals situated in the thermal effluent of a power plant with colonies upcurrent and downcurrent of the plant. Reefs were surveyed to record the sensitivity of the coral community to bleach-

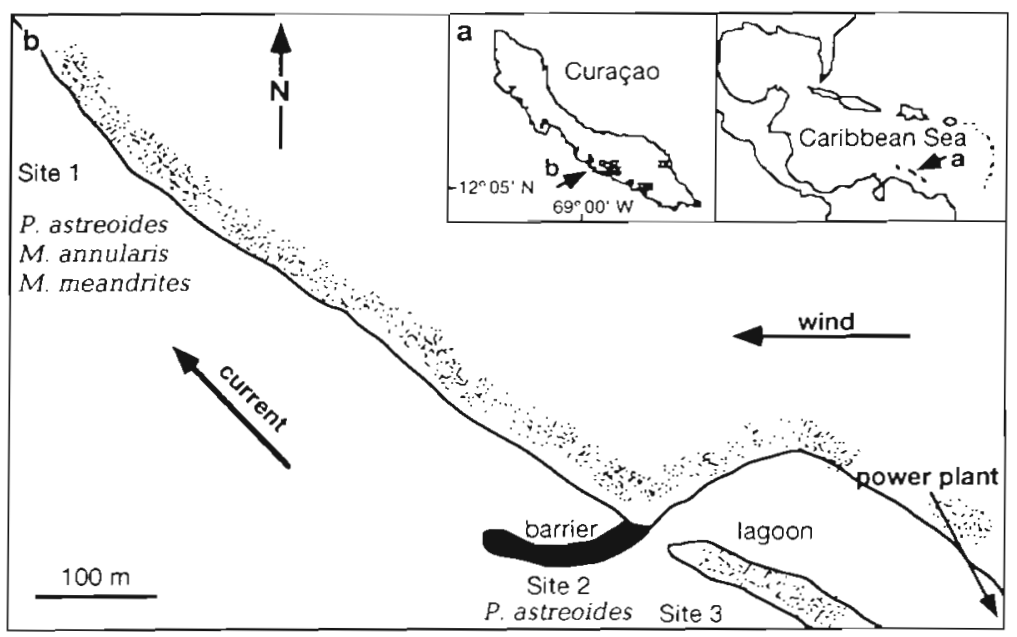

Fig. 1. Location of Curaçao and study sites. Species involved in the experiments on each site, and main wind and current directions are shown. Water is discharged by the power plant in a lagoon and flows through a small channel along a barrier of concrete and basalt blocks onto the reef ing at different sites and to assess a possible influence of the thermal effluent on community structure.

\section{MATERIALS AND METHODS}

The study sites were on the leeward coast of Curaçao, Netherlands Antilles (Fig, 1). Here fringing reefs stretch across a distance of 50 to $100 \mathrm{~m}$ from the coast to a depth of 7 to $12 \mathrm{~m}$. Seawards the reefs steeply slope to a depth of 50 to $60 \mathrm{~m}$ (Bak 1975). On these reefs, in September 1990, many colonies of various coral species started to pale, eventually turning white, in an interval of 2 to 3 wk. Not all species seemed to be equally affected, and also within species bleaching intensity varied considerably between colonies.

Three categories of colouration were observed in the field: bleached colonies - completely white colonies; partially bleached colonies - colonies displaying a reduced pigmentation compared to surrounding normal colonies or colonies showing bleached patches or patches of reduced pigmentation; and normal colonies - colonies of a colour corresponding to that observed during periods of normal seawater temperatures. In our experiment all colonies belonged to one of the unequivocal categories: bleached or normally coloured

Two regeneration experiments were carried out. The first experiment assessed the influence of bleaching on the regeneration ability of 3 common species. Artificial lesions were made on normal and bleached colonies of Montastrea annularis ( 7 November $1990 ; n_{\text {normal }}=24$, $\mathrm{n}_{\text {bleached }}=50$; depth: 7 to $\left.10 \mathrm{~m}\right)$, Porites astreoides (31 October $1990 ; n_{\text {normal }}=20, n_{\text {bleached }}=$ 27; depth: 3 to $6 \mathrm{~m})$, and Meandrina meandrites ( 6 November $1990 ; \mathrm{n}_{\text {normal }}=5$, $\mathrm{n}_{\text {bleached }}=9 ;$ depth: 17 to $25 \mathrm{~m}$ ) at Site 1 (Fig. 1). $M$. annularis is the main reefbuilding coral in Curaçao and most other places in the Caribbean. P. astreoides is very common to dominant in shallow water, though occurring down to $40 \mathrm{~m}$. $M$. meandrites is also distributed over a large depth range, but is most prominent on the reef slope (Bak 1975, 1977).

Lesions were made on top of haphazardly selected colonies with a submersible drill powered by a SCUBA tank and equipped with a small grinding point that created flat circular patches of scraped skeleton of approximately $1 \mathrm{~cm}$ diameter and $2 \mathrm{~mm}$ depth in the living coral tissue. $M$. meandrites colonies were flat (diameter: 20 to $30 \mathrm{~cm}$ ), and lesions 
were made in between the collines, on top of a polyp mouth, and approximately in the middle of the colony. $M$. annularis (the massive morphotype; Van Veghel \& Bak 1993), and $P$. astreoides colonies were approximately hemispherical (height: 40 to 80 and 12 to $25 \mathrm{~cm}$ respectively). Lesion area was measured with a plexiglass ruler divided into $2 \mathrm{~mm}$ squares. At the start of the experiments lesion depth was measured with calipers to calculate the area of the lesion wall. This area was included in the estimation of the total lesion area.

To describe coral regeneration accurately, we introduce the following definitions:

- Regeneration rate: the mean rate at which the lesions recover. This is expressed as area covered per unit of time, and is species specific.

- Lesion recovery: the mean percentage of lesion surface area recovered per unit time.

To calculate regeneration rate and lesion recovery, lesion size was followed through time. At each data point we also noted colony colour, signs of mortality, infections by other organisms and the appearance of polyps and septa. Total observation time was $131 \mathrm{~d}$.

The second experiment was carried out to investigate if long-term exposure to higher then normal seawater temperatures influences regeneration. Three series of lesions were made: (1) On bleached Porites astreoides colonies (25 October $1990 ; \mathrm{n}=32$; depth: 3 to $5 \mathrm{~m}$ ) situated in the thermal effluent of a power plant (Site 2, Fig. 1). There were no normally coloured colonies at this site. After the cooling water of the plant has been discharged into the lagoon, it flows through an outfall channel onto the reef. The thermal effluent is carried along the coast by the current, which predominantly flows in a northwesterly direction. (2) On bleached colonies (25 October 1990; $\mathrm{n}=23$; depth: 2 to $5 \mathrm{~m}$ ) that had been transplanted out of the effluent to Site 3, which was situated $100 \mathrm{~m}$ upcurrent, and assumed to be unaffected by the thermal effluent. Here temperatures were on average $1.3^{\circ} \mathrm{C}$ lower than at Site 2 (ranging from $0.5^{\circ} \mathrm{C}$ at the beginning of the experiment to $1.5^{\circ} \mathrm{C}$ at the end; this study). (3) On normally coloured colonies (25 October 1990; $\mathrm{n}=31$; depth: 2 to $5 \mathrm{~m}$ ) at Site 3.

Seawater temperatures were measured with calibrated maximum-minimum thermometers. Because of the considerable depth range between the experimental species at Site 1, 2 thermometers were used here: one in between the Porites astreoides colonies, situated at 3 to $6 \mathrm{~m}$ depth, and one between the Montastrea annularis colonies, situated at 7 to $10 \mathrm{~m}$ depth. Temperatures could be read accurately to $0.2^{\circ} \mathrm{C}$. The thermometers remained submerged during the whole period and were read at each data point ( 6 to 8 times during the research period).
To assess the sensitivity of different species to bleaching and to the possible influence of the thermal effluent, the coral communities at Sites $1 \& 3$ were surveyed in terms of coral cover, distribution, and health (tissue colour and mortality). At each site, 4 line transects of $50 \mathrm{~m}$ each were roped off parallel to the coast at 2 depths ( 3 to 5 , and 8 to $10 \mathrm{~m}, 26$ to 27 November 1990). On each line 10 random points were sampled (pointquarter method; Dodge et al. 1982). Plots of the average cumulative number of species versus transect length levelled off at $200 \mathrm{~m}$ or less, indicating that our sample size was sufficient. In addition to colony length, width, and distance to the random point, we noted colony colour (bleached, partially bleached or normal), and mortality (partially, with new dead spots surrounded by living tissue, or completely, with no living tissue left).

Statistics. Differences in regeneration rates were tested for significance by comparing the mean regenerated area $\mathrm{d}^{-1}$ after $8 \mathrm{~d}$ with Student's $t$-test (comparing bleached and normal colonies within 1 species) and 1 way ANOVA followed by multiple comparisons using the Tukey-Kramer method (comparing all Porites astreoides groups). Differences between regression slopes (lesion size versus time) were tested with the GT2-method and Gabriel's approximate method (Sokal \& Rohlf 1981). To normalise the data, lesion measurements were logarithmically transformed. Differences between frequency distributions of the condition of the colonies after $131 \mathrm{~d}$ were tested by the G-test. Threeway analyses of frequency data from the reef survey, measuring the health status of the colonies, were done by log-linear modelling (Sokal \& Rohlf 1981).

Correlation between water temperature and tissue colour was calculated with the non-parametric Spearman rank-order coefficient, and tested on a 2-tailed basis (Siegel \& Castellan 1988).

\section{RESULTS}

\section{Lesion regeneration}

Two days after the start of the experiments most lesions were already decreasing in size (Fig. 2). A tissue layer had started to grow inwards from the edge of the lesion, covering the bare skeleton. Polyps developed in the new tissue layer after approximately $1 \mathrm{wk}$. During the first week filamentous algae settled in the lesions, but this did not appear to retard lesion recovery, because they were overgrown by the coral tissue. Algae became more conspicuous later in the experiment when regeneration rate had largely decreased. Closed lesions remained visible for some time as a slightly lighter coloured, shallow depression in the skeleton. These slowly disappeared through locally 


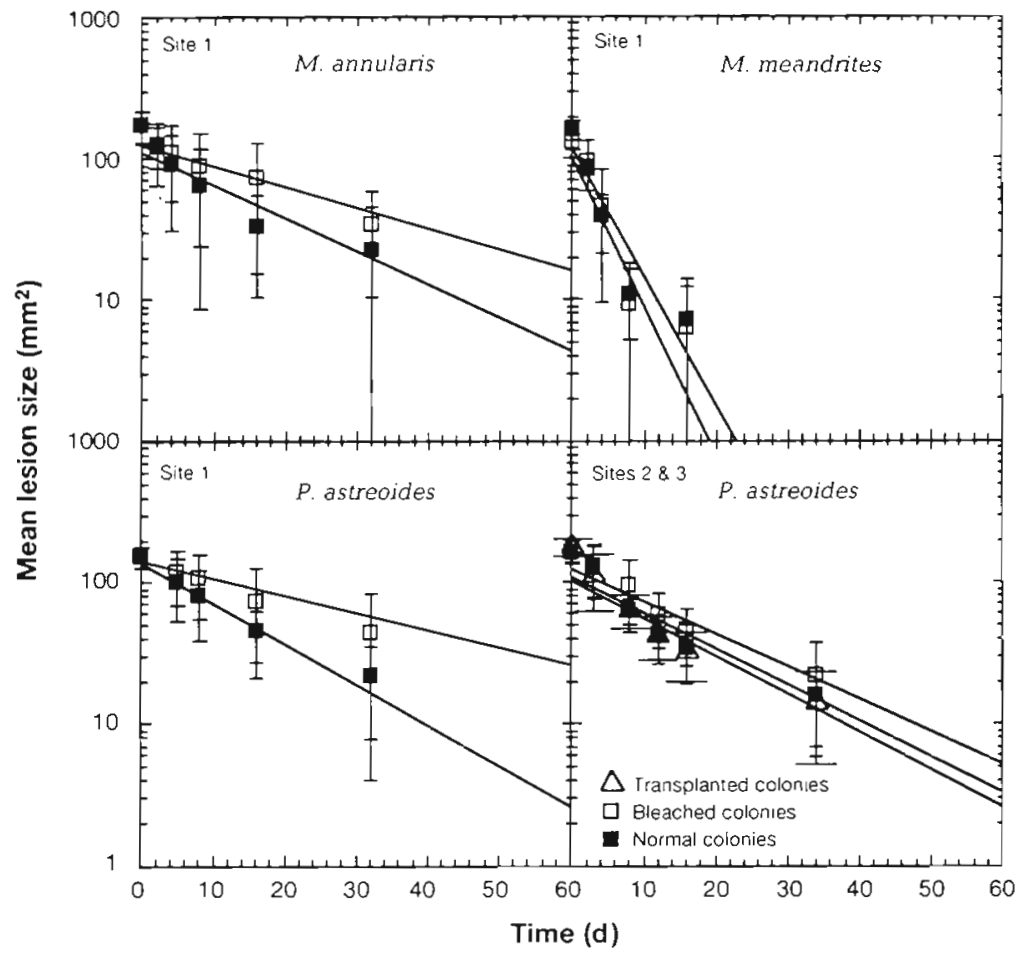

Fig. 2. Montastrea annularis, Meandrina meandrites and Porites astreoides Mean lesion surface area $\left(\mathrm{mm}^{2} \pm \mathrm{SD}\right)$ through time for regenerating lesions. Lines fitted to the exponential model Size $=a 10^{b}$ Days, calculated with $\log (x+1)$ transformed data, are shown in each graph (see also Table 2)

during the first $8 \mathrm{~d}(\mathrm{p}=0.040,1$-tailed $t$ test for differences between means). Mean regeneration rate (Fig. 3) of bleached Porites astreoides colonies $(\mathrm{n}=23$ ) was $5.4 \mathrm{~mm}^{2} \mathrm{~d}^{-1}$, while normal colonies $(\mathrm{n}=19)$ recovered at a rate of $9.0 \mathrm{~mm}^{2} \mathrm{~d}^{-1}(\mathrm{p}=$ 0.042 , 1 -tailed $t$-test). Meandrina meandrites showed the most rapid recovery (Figs. 2 \& 3). Lesions were closed at a mean rate of 18.7 (normal; $\mathrm{n}=5$ ) and 15.4 (bleached; $\mathrm{n}=9) \mathrm{mm}^{2} \mathrm{~d}^{-1}(\mathrm{p}=0.016,1$ tailed $t$-test), even though the initial lesion size in the normal group was somewhat larger than that of the bleached group (1.6 vs $1.3 \mathrm{~cm}^{2} ; \mathrm{p}=0.027,2$-tailed $t$-test). Regeneration rate in all species did not vary during the first week, but decreased sharply in the 2 following weeks.

Long-term exposure to higher temperatures probably influences regeneration (Figs. $2 \& 3$ ). Regeneration rates during the first $8 \mathrm{~d}$ were $12.4,14.3$, and $8.9 \mathrm{~mm}^{2} \mathrm{~d}^{-1}$ for normal ( $n=31$, Site 3 ), bleached transplanted ( $\mathrm{n}=23$, Site 3 ), and bleached in situ ( $\mathrm{n}=32$, Site 2 , in effluent) colonies respectively. Colonies in the effluent regenerated at the same rate as normal colonies at Site 1 (Table 1). There was no statistical difference between colonies in

increased calcification after the new polyps appeared in the tissue.

In Porites astreoides lesions small fragments of tissue sometimes occurred free of the regenerating tissue rim, probably from tissue remains located deep in the perforate skeleton. Montastrea annularis lesions always closed from the periphery of the lesion. New polyps developed in between and on the remaining calices. Lesions in Meandrina meandrites were very rapidly covered by new tissue, and new polyps developed in the old calices only. New septa appeared immediately after lesions had been closed by the tissue, and reached their original size (10 to $12 \mathrm{~mm}$ ) on Day 64.

Some lesions on bleached colonies of Montastrea annularis and Porites astreoides enlarged to many times their initial size, occasionally resulting in the death of the whole colony. Such lesions are only included in the mortality assessment.

\section{Regeneration rate}

Bleaching affected lesion regeneration of all species (Figs. 2 \& 3). Mean regeneration rate of Montastrea annularis (Fig. 3) was $10.5(\mathrm{n}=41)$ and $13.9 \mathrm{~mm}^{2} \mathrm{~d}^{-1}$ $(n=26)$ for bleached and normal colonies respectively the effluent, normally coloured colonies at Site 1, and normally coloured colonies at Site 3 . Temperature is probably the main difference between sites, and it appears likely that colonies in the effluent have become acclimatised to the higher water temperatures. Mean regeneration rate of bleached colonies transplanted

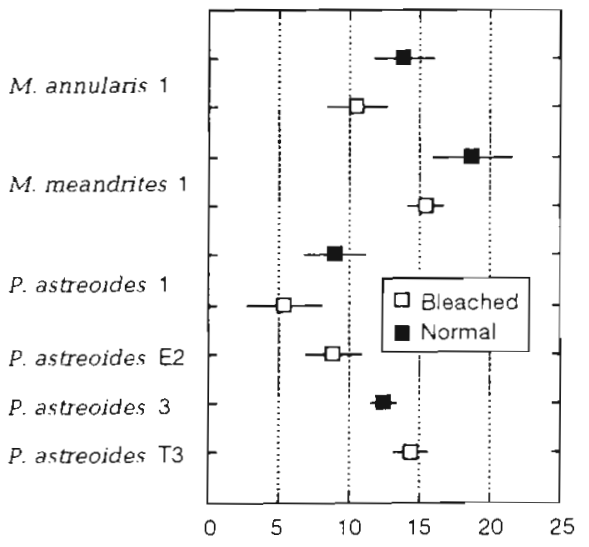

Mean regeneration rate $\left(\mathrm{mm}^{2} \mathrm{~d}^{-1}\right)$

Fig. 3. Montastrea annularis, Meandrina meandrites and Porites astreoides. Mean regeneration rate $\left(\mathrm{mm}^{2} \mathrm{~d}^{-1}\right.$ and $95 \%$ $\mathrm{CL}$ ) during the first $8 \mathrm{~d}$ following lesion infliction. Numbers refer to the different sites; $E$ : in effluent; $T$ : transplanted 
Table 1 Porites astreoides. Results of Tukey-Kramer comparisons after 1 -way ANOVA between the mean regeneration rates $\left(\mathrm{mm}^{2}\right.$ tissue regeneration $\mathrm{d}^{-1} \pm \mathrm{SE}$, bold type) of the first $8 \mathrm{~d}$ of colonies at Sites $1,2, \& 3$. B: bleached; N: normal; BE: bleached in effluent; BT bleached transplanted colonies. Significant comparisons are underlined

\begin{tabular}{|c|c|c|c|c|c|}
\hline & B Site 1 & N Site 1 & BE Site 2 & N Site 3 & BT Site 3 \\
\hline B Site 1 & $5.4 \pm 1.5$ & 0.187 & 0.117 & 0.000 & 0.000 \\
\hline N Site 1 & & $9.0 \pm 1.2$ & 0.999 & $\overline{0.181}$ & 0.010 \\
\hline BE Site 2 & & & $8.9 \pm 1.1$ & 0.066 & 0.001 \\
\hline N Site 3 & & & & $12.4 \pm 0.5$ & $\overline{0.676}$ \\
\hline BT Site 3 & & & & & $14.3 \pm 0.7$ \\
\hline
\end{tabular}

out of the effluent upcurrent to Site 3 was comparable to that of the normal colonies at Site 3 (no statistical difference). Transplantation is not likely to affect regeneration, because transplantation effects have not been found in the past (1-way ANOVA of regeneration regression coefficients comparing in situ colonies with transplanted colonies, $\mathrm{p}=0.4$; Meesters unpubl.)

\section{Lesion recovery}

Lesion recovery of bleached colonies after $8 \mathrm{~d}$ was 56 and $35 \%$ of the initial lesion surface area of Montastrea annularis and Porites astreoides respectively. At this time normal colonies had already recovered 70 and $51 \%$ respectively. Lesion recovery of both normal and bleached colonies of Meandrina meandrites was $93 \%$ of the initial lesion surface area after $8 \mathrm{~d}$. In the thermal effluent, lesion recovery after $8 \mathrm{~d}$

Table 2. Montastrea annularis, Meandrina meandrites and Porites astreoides. Results of regression calculations of lesion size through time (Fig. 2). Regression lines were fitted to the model Size $=a 10^{b \text { Days }}$ All data were $\log (x+1)$ transformed to reduce heteroscedacity. The number of days included in the regression calculation is shown in parentheses. N: normal colonies; B: bleached colonies; $\mathrm{BE}$ : bleached in effluent; BT: bleached transplanted

\begin{tabular}{|llcccc|}
\hline Experiment & & $a$ & $b$ & $\mathrm{R}^{2}$ & $\mathrm{p}$ \\
\hline Site 1 & & & & & \\
M. annularis & $\mathrm{N}(64)$ & 101 & -0.025 & 0.61 & $<0.001$ \\
& $\mathrm{~B}(104)$ & 106 & -0.013 & 0.53 & $<0.001$ \\
M. meandrites & $\mathrm{N}(16)$ & 109 & -0.091 & 0.75 & $<0.025$ \\
& $\mathrm{~B}(16)$ & 100 & -0.109 & 0.61 & $<0.050$ \\
P. astreoides & $\mathrm{N}(64)$ & 134 & -0.029 & 0.86 & $<0.001$ \\
& $\mathrm{~B}(104)$ & 134 & -0.012 & 0.43 & $<0.001$ \\
Site 2 & & & & & \\
P. astreoides & $\mathrm{BE}(64)$ & 125 & -0.023 & 0.70 & $<0.001$ \\
Site 3 & & & & & \\
P. astreoides & $\mathrm{N}(64)$ & 112 & -0.026 & 0.83 & $<0.001$ \\
& $\mathrm{BT}(64)$ & 114 & -0.027 & 0.82 & $<0.001$ \\
\hline
\end{tabular}

was $49 \%$, while normal and bleached transplanted $P$. astreoides colonies at Site 3 had recovered respectively 62 and $65 \%$.

\section{Regression analyses}

Regeneration was characterized by an exponential decrease in lesion size (Fig. 2, Table 2). Consequently, regeneration rate, being the first derivate of the regression, also decreases exponentially. All species and treatments were compared in a single comparison of regression slopes, using the data of both experiments (Fig. 4). The differences between slopes are comparable to the differences in average regenerated surface during the first $8 \mathrm{~d}$ (Table 1, Fig. 3). Regression slope of bleached colonies of Porites astreoides and Montastrea annularis was lower than in all other groups (Fig. 4). P. astreoides at Sites $2 \& 3$ (bleached in effluent, bleached transplanted to Site 3 , and normal at Site 3) regenerated at the same rate as normal colonies of $M$. annularis and $P$. astreoides at Site 1 . There was no difference between the 2 series of Meandrina meandrites, the species which regenerated much faster than all other species and treatments.

\section{Tissue colour}

The number of experimental bleached colonies that had recovered their normal pigmentation started to increase approximately 1 mo after the onset of bleaching (Fig. 5). At that time lesions had already recovered well over $70 \%$ of their initial surface area.

On Montastrea annularis pigmentation first reappeared in irregular patches on the sides of the colonies, while the upper surfaces were the last part to acquire their normal colouration. Pigmentation returned more evenly over colonies of Porites astreoides, there being no clear distinction between upper surfaces and sides. Meandrina meandrites (which was the first species to show signs of bleaching) was the first to recover pigmentation completely 


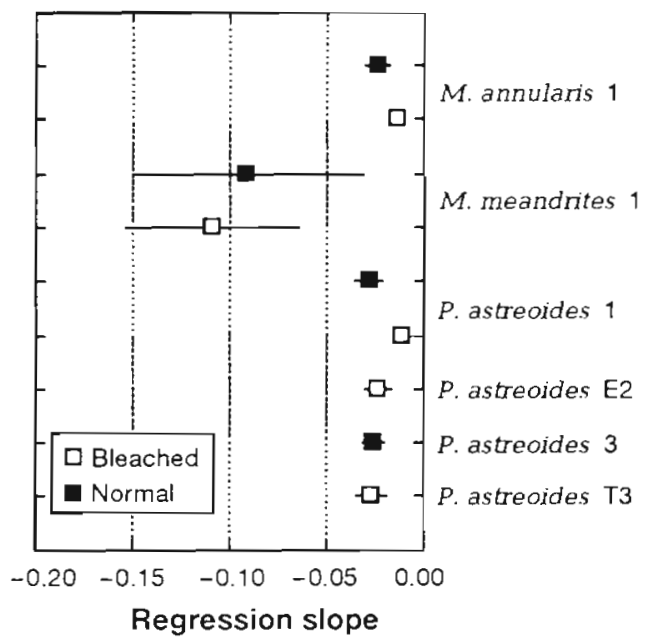

Fig. 4. Montastrea annularis, Meandrina meandrites and Porites astreoides. Regression coefficients and $95 \% \mathrm{com}$ parison intervals of the species in the 2 experiments. Slopes are significantly different at the 0.05 level if their intervais do not overlap. Site numbers as in Fig. 3

Colour restoration appeared to be negatively correlated with decreasing water temperature (Fig, 5). When the other species had already completely recovered their normal pigmentation, at the end of the

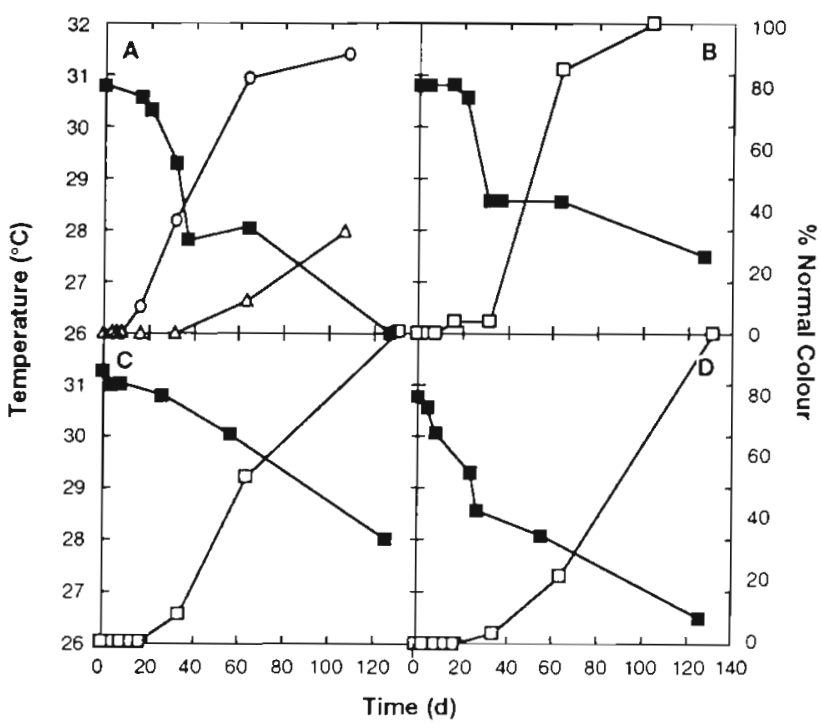

Fig. 5. Montastrea annularis, Meandrina meandrites and Porites astreoides. Mean water temperature (average of maximum and minimum temperature during preceding period) at the 3 sites during the research period, and percentage of the total number of bleached colonies in the 2 experiments that had restored pigmentation. ( ) Temperature. Spearman rank correlation coefficients $\left(r_{\mathrm{S}}\right):($ A) Site $1:(\Delta) M$. annularis $\left(r_{\mathrm{S}}=-0.68, \mathrm{p}=0.140\right) ;(0) \mathrm{M}$. meandrites $\left(r_{5}=-0.93\right.$, $\mathrm{p}=0.008)$. (B) Site 1: (ם) P. astreoides $\left(r_{\mathrm{S}}=-0.61, \mathrm{p}=0.190\right)$. (C) Site 2: (ם) P. astreoides in effluent $\left(r_{S}=-0.95, p=0.003\right)$. (D) Site 3: (口) $P$. astreoides transplanted $\left(r_{\mathrm{S}}=-0.94, \mathrm{p}=0.005\right)$ experiments, only $38 \%$ of the Montastrea annularis colonies had regained their natural colour. No normal colonies appeared until temperatures were below $27.8^{\circ} \mathrm{C}$. Pigmentation in Meandrina meandrites returned quickly, as soon as temperatures came down below $30.8^{\circ} \mathrm{C}$ (Fig. 5A).

In the effluent at Site 2 (Fig. 5C), temperatures dropped more slowly and not as much as at the other locations. Porites astreoides colonies in the effluent already recovered normal colouration when water temperature was still $30.8^{\circ} \mathrm{C}$. P. astreoides colonies at Sites $1 \& 3$ regained their normal colour only when temperatures dropped below $28.5^{\circ} \mathrm{C}$ (Fig. $5 \mathrm{~B}, \mathrm{D}$ ). Temperatures in the shallow part of Site 1 (Fig. $5 \mathrm{~B}$ ) were higher than in the deeper part (Fig. 5A). The warm water from the power plant apparently keeps close to the shore and affects the temperature around the Porites colonies, rather then around the MontastreaMeandrina group.

\section{Coral mortality}

Mortality resulted from the disappearance of bleached tissue peeled off the skeleton, and the subsequent colonization by filamentous algae of the exposed skeleton. Reactions of the experimental colonies differed between species after $131 \mathrm{~d}$ (Table 3). All lesions of Meandrina meandrites regenerated, and no mortality occurred on normal or bleached colonies. Bleached colonies of Montastrea annularis and Porites astreoides showed significantly more mortality than normal colonies. Bleached $P$. astreoides colonies in the effluent and at Site 1 suffered most, more than $90 \%$ and $60 \%$ of the colonies showing respectively signs of mortality ( $p<0.05$ for comparison of bleached colonies in the effluent with bleached colonies at Site 1). There was no significant difference between mortality patterns of bleached transplanted colonies, normal colonies at Site 3, and normal colonies at Site 1.

\section{Community structure and condition of colonies}

Colony density and coral cover differed markedly between Sites 1 \& 3 (Table 4). Mean colony density on the terrace at Site 1 is higher than at Site 3 ( $t$-test for unequal variances, $p=0.04)$. This is largely attributable to the occurrence of extremely high numbers of small Porites astreoides colonies, and to a lesser extent to a higher density of Diploria strigosa. This phenomenon also influences the terrace diversity index at Site 1, although the low number of species is mostly responsible for the lower diversity indices. Colony density at the reef-slopes is approximately 
Table 3. Montastrea annularis, Meandrina meandrites and Porites astreoides. Percentage of corals affected by different categories of mortality after $131 \mathrm{~d}$. Statistics $(G)$ and associated probabilities are given on differences between mortality categories (with total and partial mortality grouped) among bleached and normal colonies per species. Categories - closed: lesion closed, no mortality; not closed: lesion not closed and not enlarged; partial mortality: lesion enlarged; total mortality: no living tissue left. $\mathrm{n}$ : no. of colonies per group. Other codes as in Table 2

\begin{tabular}{|c|c|c|c|c|c|c|c|}
\hline Experiment & & Closed & Not closed & Partial mortality & Total mortality & $G$ & $n$ \\
\hline \multicolumn{8}{|l|}{ Site 1} \\
\hline M. annularis & $\begin{array}{l}N \\
B\end{array}$ & $\begin{array}{l}71 \\
32\end{array}$ & $\begin{array}{l}29 \\
36\end{array}$ & $\begin{array}{r}0 \\
32\end{array}$ & $\begin{array}{l}0 \\
0\end{array}$ & $\begin{array}{c}17.9 \\
(<0.001)\end{array}$ & $\begin{array}{l}24 \\
50\end{array}$ \\
\hline M. meandrites & $\begin{array}{l}N \\
B\end{array}$ & $\begin{array}{l}100 \\
100\end{array}$ & $\begin{array}{l}0 \\
0\end{array}$ & $\begin{array}{l}0 \\
0\end{array}$ & $\begin{array}{l}0 \\
0\end{array}$ & & $\begin{array}{l}5 \\
9\end{array}$ \\
\hline P. astreoides & $\begin{array}{l}\mathrm{N} \\
\mathrm{B}\end{array}$ & $\begin{array}{l}70 \\
15\end{array}$ & $\begin{array}{l}20 \\
26\end{array}$ & $\begin{array}{r}5 \\
56\end{array}$ & $\begin{array}{l}5 \\
4\end{array}$ & $\begin{array}{c}18.1 \\
(<0.001)\end{array}$ & $\begin{array}{l}20 \\
27\end{array}$ \\
\hline $\begin{array}{l}\text { Site } 2 \\
\text { P. astreoides }\end{array}$ & $\mathrm{BE}$ & 6 & 3 & 87 & 3 & & 31 \\
\hline $\begin{array}{l}\text { Site } 3 \\
\text { P. astreoides }\end{array}$ & $\begin{array}{l}\mathrm{N} \\
\mathrm{BT}\end{array}$ & $\begin{array}{l}77 \\
60\end{array}$ & $\begin{array}{r}13 \\
5\end{array}$ & $\begin{array}{l}10 \\
30\end{array}$ & $\begin{array}{l}0 \\
5\end{array}$ & $\begin{array}{c}5.2 \\
(0.07)\end{array}$ & $\begin{array}{l}31 \\
20\end{array}$ \\
\hline Total & & 47.5 & 19.4 & 33.2 & 1.8 & & 217 \\
\hline
\end{tabular}

Table 4. Colony density ( $\%$ of total number of colonies per $100 \mathrm{~m}^{2}$ reef bottom) and coral cover (\%) for each species at the shallow and deeper reef terrace at Sites $1 \& 3$. Shannon-Wiener diversity indices: $H_{n}^{\prime}=-\sum n_{i} \ln n_{i}$, and $H_{c}^{\prime}=-\sum c_{i} \ln c_{i}$, where $n_{i}=$ proportion of individuals of each species and $c_{1}=$ proportion of coverage for each species

\begin{tabular}{|c|c|c|c|c|}
\hline Species & $\begin{array}{c}\text { Site } 1 \\
(3-5 \mathrm{~m})\end{array}$ & $\begin{array}{c}\text { Site } 3 \\
(3-5 \mathrm{~m})\end{array}$ & $\begin{array}{c}\text { Site } 1 \\
(8-10 \mathrm{~m})\end{array}$ & $\begin{array}{c}\text { Site } 3 \\
(8-10 \mathrm{~m})\end{array}$ \\
\hline \multicolumn{5}{|l|}{ Density } \\
\hline Agaricia humilis & 0.0 & 1.2 & 0.0 & 2.6 \\
\hline Colpophyllia natans & 0.0 & 0.0 & 1.3 & 0.0 \\
\hline Diploria clivosa & 2.5 & 3.6 & 0.0 & 0.0 \\
\hline Dendrogyra cylindrus & 0.0 & 0.0 & 0.0 & 2 \\
\hline Dichocoenia stokesi & 0.0 & 2.4 & 21.5 & 17.2 \\
\hline Diploria strigosa & 20.1 & 23.0 & 11.4 & 17.2 \\
\hline Montastrea annularis & 0.0 & 3.6 & 10.1 & 5.3 \\
\hline Montastrea cavernosa & 0.0 & 1.6 & 6.3 & 11.3 \\
\hline Millepora complanata & 5.8 & 13.1 & 0.0 & 0.0 \\
\hline Madracis decactis & 0.0 & 0.0 & 2.5 & 0.7 \\
\hline Meandrina meandrites & 0.0 & 2.0 & 12.7 & 9.9 \\
\hline Madracis mirabilis & 0.0 & 0.0 & 5.1 & 1.3 \\
\hline Porites astreoides & 65.2 & 44.0 & 14.6 & 12.6 \\
\hline Stephanocoenia michelinii & 0.0 & 0.4 & 1.9 & 4.0 \\
\hline Siderastrea siderea & 6.4 & 4.0 & 12.7 & 14.6 \\
\hline No. of colonies & 1178 & 630 & 271 & 482 \\
\hline No. of species & 5 & 11 & 11 & 12 \\
\hline$H_{n}^{\prime}$ & 1.03 & 1.70 & 2.16 & 2.24 \\
\hline \multicolumn{5}{|l|}{ Cover } \\
\hline Dendrogyra cylindrus & 0.0 & 0.0 & 0.0 & 4.0 \\
\hline Dichocoenia stokesi & 0.0 & 0.3 & 0.8 & 1.5 \\
\hline Diploria strigosa & 2.3 & 3.4 & 0.8 & 3.3 \\
\hline Montastrea annularis & 0.0 & 0.3 & 1.3 & 1.1 \\
\hline Montastrea cavernosa & 0.0 & 0.1 & 0.3 & 1.0 \\
\hline Millepora complanata & 0.6 & 1.5 & 0.0 & 0.0 \\
\hline Meandrina meandrites & 0.0 & 0.0 & 0.4 & 1.0 \\
\hline Madracis mirabilis & 0.0 & 0.0 & 0.5 & 1.4 \\
\hline Porites astreoides & 3.0 & 1.4 & 0.8 & 0.2 \\
\hline Siderastrea siderea & 0.3 & 0.3 & 0.5 & 2.5 \\
\hline Total cover & 6.2 & 7.3 & 5.4 & 16.0 \\
\hline$H_{c}^{\prime}$ & 1.27 & 1.6 & 2.17 & 2.02 \\
\hline \multicolumn{5}{|l|}{ Average $( \pm S D), n=4$} \\
\hline Density $\left(\mathrm{m}^{-2}\right)$ & $12.08 \pm 3.47$ & $6.34 \pm 0.52$ & $3.03 \pm 1.45$ & $5.81 \pm 2.90$ \\
\hline Cover & $6.80 \pm 2.61$ & $7.70 \pm 2.40$ & $7.41 \pm 4.26$ & $17.07 \pm 4.34$ \\
\hline
\end{tabular}


equal between the 2 sites ( $\mathrm{p}=0.14$; $t$-test). Mean coral cover on the reef terrace is not statistically different between the 2 sites ( $p=0.63)$, but differs between the respective reef-slopes. At Site 3, upcurrent from the power plant outfall, coral cover was more than twice the cover at Site $1(p=0.02)$.

The surveyed colonies were classified as normal, partially bleached, completely bleached, partially dead, or completely dead (Fig. 6). At the time of the survey only a single Porites astreoides colony and a few Millepora complanata colonies on the terrace at Site 1 showed signs of mortality. Apart from the difference in species number between the terrace at Sites 1 $\& 3$, bleaching was more pronounced at Site 1 ( $p=$ 0.016 , test for 3-factor interaction using log-linear model). Species on the terrace of Site 1 were equally affected $(p=0.12)$, while the same species at Site 3 were not $(p<0.001)$, indicating possibly different environmental conditions al the 2 sites. Both reefslope sites were equally affected $(p=0.22$, test for 3 -factor interaction), and species differed in the way they were affected $(p<0.0001)$. Of the surveyed Montastrea annularis colonies and Dichocoenia stokesi 100 and $88 \%$ respectively were bleached or partly bleached. In contrast, only $19 \%$ of $P$. astreoides were bleached.

\section{DISCUSSION}

This study shows that regeneration is not only species specific, but also negatively influenced by bleaching. Regeneration rates of corals have been shown to be species specific, and associated with life history strategies (Bak et al. 1977, Bak \& Steward - van
Es 1980, Bak 1983). A species such as Acropora palmata, fast growing, and recruiting mainly through fragmentation (Bak \& Engel 1979), regenerates small lesions very rapidly (Bak 1983). Contrastingly, Agaricia agaricites, growing more slowly and depending for propagation mainly on sexual reproduction (Bak \& Engel 1979), is a poor regenerator (Bak \& Steward-van Es 1980). In this study, bleached colonies of Montastrea annularis, Porites astreoides, and Meandrina meandrites regenerated their lesions more slowly than normal colonies.

Coral tissues are damaged continually through the activities of fishes, echinoids, asteroids, molluscs, polychaetes, microorganisms, and man (reviews by Pearson 1981, Brown \& Howard 1985, Hutchings 1986). Invasion of these patches by other organisms, such as excavating sponges or algae, may result in weakening of the skeleton or in overgrowth, and subsequent death of the whole or part of the colony. At least 2 factors are important in this process. Firstly, regeneration rates decrease exponentially through time, as was shown by the good fit to exponential regression lines (Table 2). Secondly, the lesions are invariably colonized by filamentous algae which become conspicuous after 2 to $3 \mathrm{wk}$. A result of the first factor is that larger lesions on corals may not close at all (e.g. Bak \& Steward-van Es 1980). During this study we never observed regeneration of the large lesions, resulting from mortality of bleached tissue. Lesions on normai colonies close more efficiently even though they are also always colonised by algae. It appears that the simple presence of filamentous algae is not important as long as there is active regeneration (Bak \& Steward - van Es 1980).

Meandrina meandrites regenerated extremely rapidly. A difference in the regeneration rate between normal

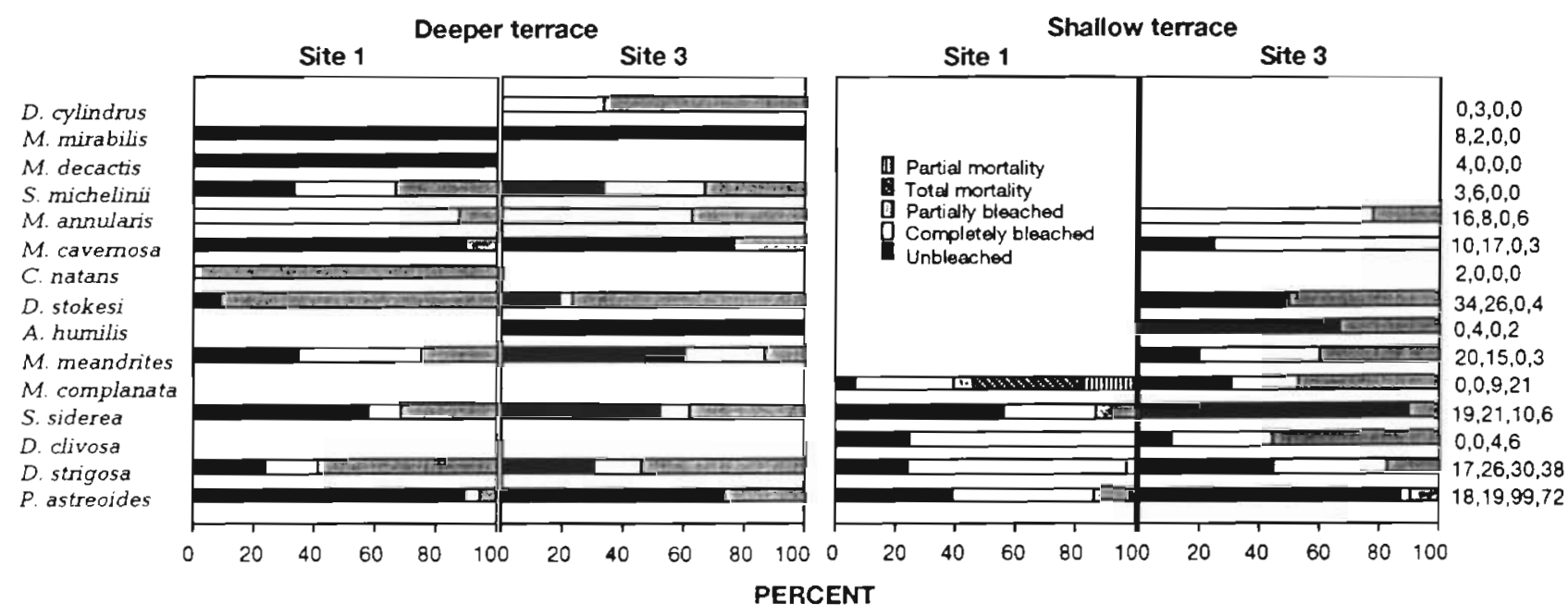

Fig. 6. Colony condition of the species at the shallow and deeper terrace of Sites 1 \& 3. Total number of colonies per species per site are given at end of bars at right. Species as in Table 4 
and bleached colonies could only be measured during the first $8 \mathrm{~d}$. At the next survey, after $16 \mathrm{~d}$ regeneration, many lesions of both normal and bleached colonies had already closed. The lack of difference between the regression coefficients of $M$. meandrites must be attributed to the low numbers of colonies in the experiment, and the fact that the initial lesions were larger in normal colonies than in bleached colonies.

Our field study strongly suggests that the corals living in the power plant effluent have become acclimatised. Regeneration rate of bleached Porites astreoides colonies situated in the thermal effluents of a power plant was just as high as that of normal colonies at the other 2 sites. Furthermore, they regained their normal colour at higher temperatures than colonies in the other experiment. Colonies transplanted out of the effluent upcurrent also regenerated at a rate comparable to normally coloured colonies. Previous laboratory studies have already indicated the possibility of corals acclimatizing to higher than ambient temperatures (Clausen \& Roth 1975, Coles \& Jokiel 1978).

The power plant is suspected to have changed community structure at the shallow part of Site 1, $500 \mathrm{~m}$ downcurrent, where Porites astreoides and Diploria strigosa densities were higher, and diversity was lower, when compared to Site 3, upcurrent of the power plant. Positive effects on coral recruitment have been reported by Edmondson (1946) and Coles (1984), who found increased settlement rates at higher temperatures.

A delayed effect of bleaching was indicated by the increase in mortality of bleached colonies at a time when water temperature was approaching normal values, colonies had almost regained their normal colour, and the majority of the lesions were almost closed. This could mean that colonies were drawing on their reserves, which became depleted during this period. Davies (1991) estimates that through metabolisation of lipid reserves corals can survive periods of low photosynthetic productivity for 28 to $114 \mathrm{~d}$. Mortality was especially high for corals in the effluent, which might indicate that their reserves were less than those of the other corals. During this study Montastrea annularis was not as badly affected by mortality as the other species, but later observations on the reef terrace showed severe mortality on top of many columnar and massive colonies. Most lesions, resulting from the death of bleached patches, will not recover because they are too large. Our reef survey, which was done at the time when water temperatures were highest, indicates that all $M$. annularis colonies displayed signs of bleaching. The fact that in our experiments $M$. annularis was the last species to start recovery, and that $30 \%$ of our experimental colonies showed signs of partial mortality, indicates that $M$. annularis is very sensitive to bleaching and consequent mortality. From a conservation and management point of view it appears strongly advisable to reduce human activities in times of stress to limit possible damage to corals as much as possible, because the ability of corals to regenerate damage appears to decrease under stress.

In conclusion, bleaching limits the potential of corals to recover from small wounds. Small patches of bare skeleton may enlarge, resulting in partial or total death of the colony. Mortality in corals, among them Montastrea annularis, the main reef-building coral in the Caribbean, was very high, when damaged in bleached condition

Acknowledgements. We thank the Carmabi dive buddies for their help and advice, $M$. Brown and $O$. Wijker for their assistance under water and J. Vermeulen and G. Nieuwland for logistical support. The manuscript benefitted from the comments of $\mathrm{L}$. Fernandes and 3 anonymous reviewers. This research was supported by a grant from the Netherlands Foundation for the Advancement of Tropical Research (WOTRO) W84-311.

\section{LITERATURE CITED}

Bak, R. P. M. (1975). Ecological aspects of the distribution of reef corals in the Netherlands Antilles. Bijdr. Dierk. 45: $181-190$

Bak, R. P. M. (1977). Coral reefs and their zonation in Netherlands Antilles. Studies in Geology, AAPG 4: 3-16

Bak, R. P. M. (1978). Lethal and sublethal effects of dredging on reef corals. Mar. Biol. 9: 14-16

Bak, R. P. M. (1983). Neoplasia, regeneration and growth in the reef-building coral Acropora palmata. Mar. Biol. 77: 221-227

Bak, R. P. M., Brouns, J. J. W. M. Heys, F. M. L. (1977). Regeneration and aspects of spatial competition in the scleractinian corals Agaricia agaricites and Montastrea annularis. Proc. 3rd int. Symp. coral Reefs 143-149

Bak, R. P. M., Elgershuizen, J. H. B. W. (1976). Patterns of oilsediment rejection in corals. Mar. Biol. 37: 105-113

Bak, R. P. M., Engel, M. S. (1979). Distribution, abundance and survival of juvenile hermatypic corals (Scleractinia) and the importance of life history strategies in the parent coral community. Mar. Biol. 54: 341-352

Bak, R. P. M., Steward-van Es, Y (1980). Regeneration of superficial damage in the scleractinian corals Agaricia agancites f. purpurea and Porites astreoides. Bull. mar. Sci. 30: 883-887

Bak, R. P. M., Van Eys, G. (1975). Predation by the sea urchin Diadema antillarum Philippi on living coral. Oecologia 20: 111-115

Brown, B. E. (ed.) (1990). Bleaching. Coral Reefs, Special issue 8(4): $135-232$

Brown, B. E., Howard, L. S. (1985). Assessing the effects of 'stress' on reef corals. Adv. mar. Biol. 22: 1-63

Clausen, C., Roth, A. A. (1975). Effect of temperature adaptation on calcification rate in the hermatypic coral Pocillopora damicornis. Mar. Biol. 33: 93-100

Coles, S. L. (1984). Colonization of Hawaiian reef corals on new and denuded substrata in the vicinity of a Hawailan power station. Coral Reefs 3: 123-130 
Coles, S. L., Jokiel, P. L. (1977). Effects of temperature on photosynthesis and respiration in hermatypic corals. Mar. Biol. 43: 209-216

Coles, S. L., Jokiel, P. L. (1978). Synergistic effects of temperature, salinity and light on the hermatypic coral Montipora verrucasa. Mar. Biol. 49: 187-195

Cook, C. B., Logan, A., Ward, J., Luckhurst, B., Berg, C. J. Jr (1990). Elevated temperatures and bleaching on a high latitude coral reef: the 1988 Bermuda event. Coral Reefs 9: $45-49$

Dodge, E. D., Logan, A., Antonius, A. (1982). Quantative reef assessment studies in Bermuda: a comparison of methods and preliminary results. Bull. mar. Sci. 32: 745-760

Davies, P. S. (1991). Effect of daylight variations on the energy budgets of shallow-water corals. Mar. Biol. 108: 137-144

Edmondson, C. H. (1946). Behavior of coral planulae under altered saline and thermal conditions. Bernice P. Bishop Mus. Occ. Pap. 18: 283-304

Endean, R. (1973). Destruction and recovery of coral reef communities. In: Jones, O. A, Endean, R. (eds.) Biology and geology of coral reefs, 1II, Biology 2. Academic Press, New York, p. 215-254

Gates, R. D. (1990). Seawater temperature and sublethal coral bleaching in Jamaica. Coral Reefs 8: 193-197

Glynn, P. W. (1984). Widespread mortality and the 1982-1983 El Nin̄o warming event. Environ. Conserv. 11: 133-146

Goreau, T. J., Macfarlane, A. H. (1990). Reduced growth rate of Montastrea annularis following the 1987-1988 coralbleaching event. Coral Reefs 8: 211-215

Hutchings, P. A. (1986). Biological destruction of coral reefs. Coral Reefs 4: 239-252

Jackson, J. B. C., Coates, A. G. (1986). Life cycles and evolution of clonal (modular) animals. Phil. Trans. R. Soc. B 313: 7-22

Jokiel, P. L., Coles, S. L. (1974). Effects of heated effluents on hermatypic corals at Kahe Point, Oahu. Pacif. Sci. 28: 1-18

Jokiel, P. L., Coles, S. L. (1977). Effects of temperature on the mortality and growth of Hawaiian reef corals. Mar. Biol. 43: 201-208

Jokiel, P. L., Coles, S. L. (1990). Response of Hawaiian and other Indo-Pacific reef corals to elevated temperature. Coral Reefs 8: 155-162

Jokiel, P. L., Guinther, E. B. (1978). Effects of temperature on reproduction in the hermatypic coral Pocillopora damicornis. Bull. mar. Sci. 28: 786-789

This article was submitted to the editor
Kinzie, R. A. III, Jokiel, P. L., York, R. H. Jז (1984). Effects of light of altered spectral composition on coral zooxanthellae associations and on zooxanthellae in vitro. Mar. Biol. 78: 239-248

Lang, J. C., Chomesky, E. A. (1990). Competition between scleractinian reef corals - a review of mechanisms and effects. In: Dubinsky, Z. (ed.) Ecosystems of the world 25, Coral reefs. Elsevier, Amsterdam, p. 209-252

Lasker, H. R., Peters, E. C., Coffroth, M. A. (1984). Bleaching of reef coelenterates in the San Blas Islands, Panama. Coral Reefs 3: 183-190

Loya, Y (1972). Community structure and species diversity of hermatypic corals at Eilat, Red Sea. Mar. Biol. 13: 100-123

Loya, Y. (1976). Skeletal regeneration in a Red Sea scleractinian coral population. Nature 261: 490-491

Ott, B., Lewis, J. B. (1972). The importance of the gastropod Coralliophila abbreviata (Lamarck) and the polychaete Hermodice carunculata (Pallas) as coral reef predators. Can. J. Zool. 50: 1651-1656

Pearson, R. G. (1981). Recovery and recolonization of coral reefs. Mar. Ecol. Prog. Ser. 4: 105-122

Rinkevich, B., Loya, Y. (1989). Reproduction in regenerating colonies of the coral Stylophora pistillata. In: Spanier, E., Steinberger, $Y$., Luria, M. (eds.) Environmental quality and ecosystem stability, IV B, Environmental quality. Hebrew University, Jerusalem, p. 257-265

Roberts, H. H., Rouse, L. J. Jr, Walker, N. D., Hudson, J. H. (1982). Cold-water stress in Florida Bay and northern Bahamas: a product of winter cold-air outbreaks. J. sedim. Petrol. 52: 145-155

Siegel, S., Castellan, N. J. (1988). Nonparametric statistics for the behavioral sciences, 2nd edn. McGraw-Hill, New York

Sokal, R. R., Rohlf, F. J. (1981). Biometry. W. H. Freeman and Co., New York

Stoddart, D. R. (1963). Effects of Huricane Hattie on the British Honduras reefs and cays, October 30-31, 1961 Atoll. Res. Bull. 95: 1-142

Szmant, A. M., Gassman, N. J. (1990). The effects of prolonged bleaching on the tissue biomass and reproduction of the reef coral Montastrea annularis. Coral Reefs 8: 217-224

Van Veghel, M. L. J., Bak, R. P. M. (1993). Intraspecific variation of a dominant Caribbean reef building coral, Montastrea annularis: genetic, behavioral and morphometric aspects. Mar. Ecol. Prog. Ser. 92: 255-265

Manuscript first received: February 14, 1992

Revised version accepted: March 24, 1993 